\title{
Geographic distribution of ebony leaf monkey Trachypithecus auratus (E. Geoffroy Saint-Hilaire, 1812) (Mammalia: Primates: Cercopithecidae)
}

\author{
Vincent Nijman \\ Institute for Systematics and Population Biology (Zoological Museum), University of Amsterdam, P.O. Box \\ 94766, 1090 GT Amsterdam, The Netherlands
}

Key words: Bali, Colobinae, colobine monkeys, distribution, Indonesia, Java, langur, Lombok, primates

\begin{abstract}
As one of the fundamental units of ecology and biogeography, the geographic distribution of the endemic and threatened ebony leaf monkey Trachypithecus auratus (E. Geoffroy Saint-Hilaire, 1812) on the islands of Java, Bali, and Lombok (Indonesia) has been assessed. All localities where the species has been collected are listed, and forty-two areas (each in itself consisting of numerous smaller sites) where the species has been recorded are discussed. The species occurs in a large variety of forest types, including mangrove, beach, and freshwater swamp forest; everwet lowland and hill forest; dry decidious forest; montane forest up to 3,000-3,500 m a.s.l.; and in some forest plantations (teak Tectona grandis, rasamala Altingia excelsa, acacia Acacia spp). In East Java, certain populations are dimorphic, contaîning, besides the more common melanic individuals, also erythristic individuals. This erythristic pelage morph only occurs in the easternmost part of Java of which the line between Mt. Penanggunang and the surroundings of Mojokerto running southwards, via Wonosalam and Blitar, to Mts Kidul roughly forms the western boundary. Localities where individuals of the erythristic pelage morph have been collected or observed are given.
\end{abstract}

\section{Contents}

$\begin{array}{lr}\text { Abstract } & 157 \\ \text { Introduction } & 157 \\ \text { Methods } & 159 \\ \text { Results } & 160 \\ \quad \text { Province of West Java (incl. DKI Jakarta) } & 160 \\ \text { Province of Central Java (incl. DI Yogyakarta) } & 164 \\ \text { Province of East Java } & 167 \\ \text { Island of Bali } & 170 \\ \text { Island of Lombok } & 170 \\ \text { Discussion } & 171 \\ \text { Habitat and range } & 171 \\ \text { Distribution of the erythristic pelage morph } & 173 \\ \text { Acknowledgements } & 174 \\ \text { References } & 174\end{array}$

\section{Introduction}

Being located in the extreme east of the Sundaic subregion, Java and Bali are the most isolated of the remaining land masses and also furthest from the Asian mainland. Java harbours a slightly impoverished non-human primate fauna compared to the other Sundaic islands. There are 5 species, including one nocturnal prosimian, the slow loris Nycticebus coucang, compared to 13 species on Borneo and 12-13 species on mainland Sumatra; the exact species number depends on the taxonomy followed. However, a relative high proportion of them are endemic, viz. $60 \%$ (compared to $38-43 \%$ on Borneo, and $8-17 \%$ on mainland Sumatra). The endemics comprise one species of Hylobatidae, the Javan or silvery gibbon Hylobates moloch (Audebert, 1799) and two species of Colobinae, the grizzled leaf monkey Presbytis comata (Desmarest, 1822) and the ebony leaf monkey' Trachypithecus auratus (E. Geoffroy Saint-Hilaire, 1812). The Javan gibbon and the grizzled leaf monkey are confined to the wettest forest types, which are more common to the western part of the island, and can be found as far east as Mts Dieng and Mt. Lawu, respectively (Nijman and Sözer, 1995; Nijman, 1995, 1997). The ebony leaf monkey's range encompasses a larger area, and the species can be found in other

\footnotetext{
I Ebony leaf monkey is also known as ebony, moor or negro langur, Javan leaf monkey / langur, silver(ed) leaf monkey / langur, amongst others. Some of these names, however, are also used for the grizzled leaf monkey Presbytis comata and silvered leaf monkey Trachypithecus cristatus. Locally ebony leaf monkeys are known as either lutung (both melanic and erythristic individuals) and in parts of East Java budeng (usually only the melanic individuals)
} 
forest types as well, on Java, Bali and Lombok. ${ }^{2}$ Despite its distribution encompassing a larger area than the other Javan endemics, its range is still restricted, and its habitat has largely dissappeared. Ebony leaf monkey are listed as Vulnerable according to the IUCN threat criteria (Eudey, 1987; IUCN, 1996). The species is listed on Appendix II of the CITES convention.

The ebony leaf monkey has for a long-time been regarded as conspecific with the silvered leaf monkey, T. cristatus (e.g., Pocock, 1935; Napier, 1985; Wolfheim, 1983), but it was given its specific status by Weitzel and Groves (1987). The species specific status of $T$. auratus is now generally accepted (e.g., Weitzel et al., 1988; IUCN, 1994; Brandon-Jones, 1984, 1995; Corbet and Hill, 1992; Oates et al., 1994; Maryanto et al., 1997). $T$. cristatus and $T$. auratus occur allopatrically with the former having a disjunct distribution with populations from southern Burma, southern Thailand, Cambodia and southern Laos and Vietnam, and from the western coast of West Malaysia, Sumatra and Borneo (Corbet and Hill, 1992), while the latter, as stated before, ranges from Java eastwards to Lombok. Both species can be distinguished by skull and dental characters (Weitzel and Groves, 1987; Maryanto et al., 1997). Furthermore, T. cristatus is brown, brownish-grey or blackish brown, while the Javan species is more blackish tingled with brown and grey. In both species some populations are polymorphic in pelage coloration, with melanic and usually a small proportion of erythristic individuals occurring together. This proportion may vary between areas. In the ebony leaf monkey, these populations are restricted to the easternmost part of Java (see Discussion), while in the silvered leaf monkey these populations hitherto only have been recorded from Abai at the mouth of the Kinabatangan River in eastern Sabah, Borneo (Davis, 1962; Payne et al., 1985). Weitzel and Groves (1987) concluded that the type specimen of $T$, auratus,

\footnotetext{
${ }^{2}$ Based on a single skin, probably originating from the northwestern part of Vietnam, Brandon-Jones (1984, 1995) described subspecies Semnopithecus (Trachypitecus) auratus ebenus. As it is of little relevance to the present paper, and pending more information on this taxon and its distribution, it is not discussed further.
}

an erythristic female, must have originated from the easternmost part of Java (see also BrandonJones, 1995).

Little is known about the ecology of the species in natural forest areas, since only a limited number of studies have been conducted so far. Most of the comprehensive studies, i.e., those of Brotoisworo and Dirgayusa (Brotoisworo, 1983; Brotoisworo and Dirgayusa, 1991), Kool (1993; Kool and Croft, 1992), and to a lesser extend Megantara (1994) have been conducted in the Pangandaran nature reserve. Pangandaran is a small c. 500 ha. uplifted limestone peninsula at the southeastern corner of West Java. Parts of the area are covered with teak, Tectona grandis and mahogany, Swietenia spp., stands, while the remainder consists of rather dry evergreen forest (Whitten et al., 1996). Data presented by Brotoisworo (1983) suggest densities of c. 185 to 195 individuals $\mathrm{km}^{-2}$. Typical densities in areas where the species has been studied, which are often selected because the species is relatively common, range in the order of 20 to 75 individuals km² (Kartikasari, 1986; Supriatna et al., 1988; Bismark and Wiryosoeparto, 1980 in Supriatna et al., 1988; Nijman and van Balen, 1998), with probably the more typical density leaning towards the lower figure (unpubl. data). Pangandaran receives more visitors than any other conservation area in Indonesia, possibly 500,000 annually (Whitten et al., 1996), quite possibly having an effect on the socio-ecology and structure of the ebony leaf monkey population. Hence, findings and conclusions arising from studies conducted on the species in Pangandaran are probably not representative and cannot unhesitatingly be extrapolated to other areas.

As many other species within the genus Trachypithecus, the ebony leaf monkey lives in groups with one adult male and a number of immature males, females, and young (see reviews by Bennett and Davies, 1994; Newton and Dunbar, 1994). These group sizes range from 3 to over 30 individuals (pers. observ.; Supriatna et al., 1988; Brotoisworo, 1983). Group sizes on Java seem to differ between areas with different climatic conditions; median group sizes in areas with a more pronounced dry season, which are mainly found 
in the eastern half of Java as well as along the island's northern coast, tend to be larger than those found in areas with a perhumid climate (unpubl. data). Extra-group males either live as solitaries or can team up with other bachelor males in bands or small groups (pers. observ.; Bennett and Davies, 1994; Brotoisworo, 1983).

A number of studies have been performed on the species' feeding behaviour (Kartikasari, 1986; Supriatna et al., 1988; Brotoisworo and Dirgayusa, 1991; Kool, 1993; Djuwantoko et al., 1994) often partially in teak plantations. Like all colobines, ebony leaf monkeys possess a fore-stomach digestive system, which allows them to break down cellulose (Bauchop and Martucci, 1968; Kay and Davies, 1994). This makes the species able to cope with a substantial amount of foliage, a relative unnutricious food source, in their diet (for an overview of food selection in colobines see e.g., Waterman and Kool, 1992). Indeed, although depending on habitat type and seasonality, a large part of their diet consists of leaves and flowers (55\% and 67\% Kool, 1993; 56\% Kartikasari, 1986; $59 \%$ Supriatna et al., 1988; $90 \%$ Brotoísworo and Dirgayusa, 1991; 94\% Djuwantoko et al., 1994). As in most colobines, ripe fruits is not a favoured food source, and often only the seeds are consumed. When fruit is eaten, e.g., figs Ficus spp, mahogany Swietenia macrophylla, and acacia Acacia leucophloea, it is mostly not ripe (Kool, 1993; Kartikasari, 1986).

The geographic distribution of a species is perhaps the fundamental unit of ecology and biogeography. It affects probability of extinction (Jablonski, 1987) and different range sizes of species ultimately determine the number of species in a given area. The distribution of a species is determined by its geographical range and by the evenness or patchiness of occurrence within its range. Ecological analysis of species distribution patterns depends on the accuracy of the distributional data on which it is based: if a distributional pattern has been incorrectly described any interpretation of that pattern will be erroneous (cf. Wiens, 1992). Brockelman and Ali (1987) stress the importance of publishing reliable and detailed data on the distribution of primates. The need for accurate mapping of species" ranges, their relevance to biogeographic processes and the structure of local species assemblages, and the potential sources of error in estimating species-range-size distributions have recently been discussed by Jones (1998) and Gaston (1996). Furthermore, for the proper assessment of a species" conservation status and in order to monitor changes in abundance, range, and status an accurate description of its range of occurrence is essential. Therefore, as part of an ongoing study on the ecology and conservation status of ebony leaf monkey, the present paper attempts to thoroughly assess the geographical distribution of ebony leaf monkeys on Java, Bali and Lombok.

\section{Methods}

The data originate from surveys conducted by the author over a period of 16 months in-March-September 1994, June-July 1995, August-September 1997 and September 1998-January 1999 on Java, Bali, Madura, and Kangean. Some additional data were collected in the period June 1999-February 2000. The presence or absence of ebony leaf monkeys was assessed by surveying inside the forest and by scanning over the forest from vantage points (hill tops or forest edge). In all, 206 days were spent surveying in forest areas (excluding those areas where neither I nor any other recorded the species). While in the forest areas additional information on the presence of ebony leaf monkeys was gathered by interviewing local inhabitants in Bahasa Indonesia.

These findings were supplemented with data derived from the literature, information from collected specimens stored in various museums, and from personal correspondence with other observers. All records listed are those of the author, unless stated otherwise. Areas in which ebony leaf monkeys were observed are listed by province and in a west to east sequence. For each area the county names in which it is situated is given, a short description of the type of habitat is presented, the status and records of ebony leaf monkeys in that area are listed, as are the specimens, if any, which have been collected. Specimens collected were either collected in the described area itself or the described area nearest to the site of collection.

Abbreviations employed for the institutions at which the specimens are stored are: ZMA: Zoological Museum Amsterdam, the Netherlands; RMNH: Natural Museum of Natural History, Leiden, the Netherlands (many skins have only a collector's number and no access number); MZB; Museum Zoologicum Bogoriense, Bogor, Indonesia; BMNH: Natural History Museum, London, UK; ZRC: Zoological Reference Collection, Singapore.

Note that some areas discussed in fact constitute of numerous isolated patches of forest, and that ebony leaf monkeys are not 


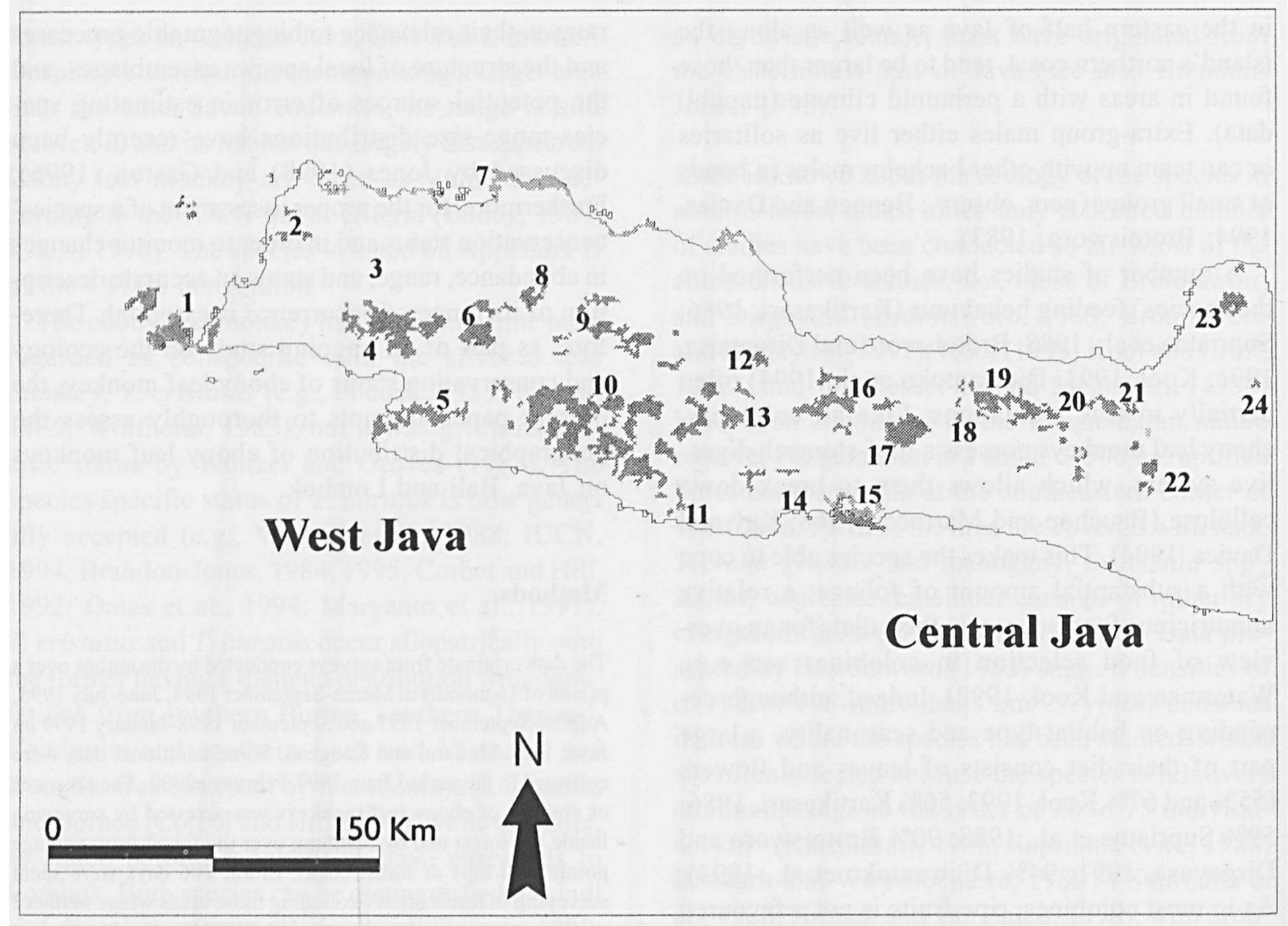

Fig. 1. Geographical distribution of ebony leaf monkey Trachypithecus auratus (E. Geoffroy Saint-Hilaire, 1812) on Java, Bali, and Lombok, Indonesia. The map shows areas covered with natural forest (after RePPProT 1990), and the areas where Trachypithecus auratus has been recorded. Note that on this scale many small areas of forest do not show. The stippled line includes the area from where individuals of the erythristic pelage morph have been recorded. Area numbers correspond with descriptions in the Chapter Results.

by definition present throughout the entire area. Furthermore, within forest areas ebony leaf monkeys may prefer certain parts above others.

Localities from where information was received about the presence of individuals of the erythristic pelage morph, either from direct observations, from hearsay evidence or from other biologists working in the area, as well as localities from where erythristic specimens have been collected, are indicated.

\section{Results}

For the geographic location of of the areas discussed in this section, see Fig. 1. All localities are discussed in a west to east sequence, and are classed by province.

\section{Province of West Java (including DKI Jakarta)}

\section{Ujung Kulon}

County: Pandeglang.

Habitat: Ujung Kulon is a more than $750 \mathrm{~km}^{2}$ area of old secondary lowland forest, with primary forest in the higher parts. The peninsula is relatively secure from logging and encroachment, but the mainland part is threatened by surrounding cultivation.

Status: The species is present mainly in the coastal zone and along the rivers, but also in the interior (Hoogerwerf, 1970). Hoogerwerf observed ebony leaf monkey mainly in the peninsular part of the reserve; but the species is also present on the 


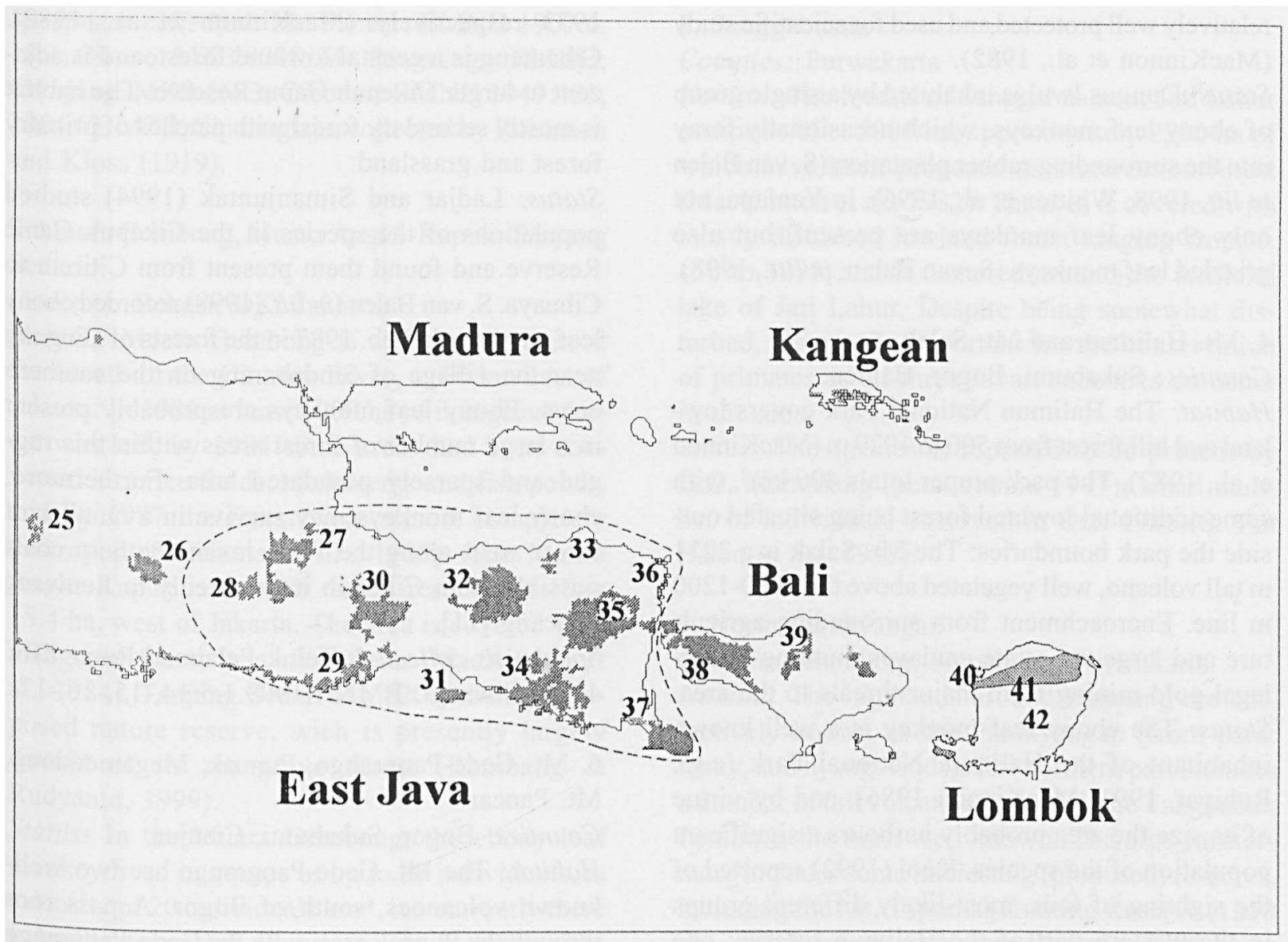

mainland on Mt. Honje (Gurmaya et al., 1992; Ruhiyat, 1991). The species is not present on Peucang or Panaitan island (Hoogerwerf, 1970). Specimens collected: Niur: MZB 6694.

\section{Ranca Danau, Mt. Karang and Mt. Aseupan} Counties: Pandeglang, Serang.

Habitat: Fragmented patches of forest with the last remaining substantial area of fresh water swamp forest in Ranca Danau totalling c. $250 \mathrm{~km}^{2}$, while another $170 \mathrm{~km}^{2}$ is present in two patches in the adjacent Gunung Tukung Gede Nature Reserve. Several thousands of hectares of disturbed lowland forest remain on Mt. Aseupan, while c. 100 ha of lowland forest is protected as recreation forest near the Curug Gendang waterfalls, Carita. On Mt. Karang c. $30 \mathrm{~km}^{2}$ of montane forest remains ranging from c. $1000-1778 \mathrm{~m}$.

Status: A small number of groups were observed near the waterfalls, as well as near the guard post at the entrance of the recreation forest at Carita
(Sept. 1997); one group was observed to foray into the adjacent Rasamala Altingia excelsa plantation. S. van Balen (in litt., 1998) recorded the species on the $1346 \mathrm{~m}$ tall Mt. Pulosari, c. $6 \mathrm{~km}$ south-east of Mt. Aseupan (Oct. 1995). The species is present in the swamp forests of Ranca Danau and hill forest of Mt. Tekung Gede (Melish and Dirgayusa, 1996), as well as in the montane forests of Mt. Karang (April 1995: S. van Balen in litt. 1998). Specimens collected: Ujungtebu: ZRC 4382.

\section{Dungus Iwul and Yanlapa}

County: Bogor.

Habitat: Dungus Iwul is a small relict patch of primary forest ( 9 ha) surrounded by rubber Hevea brasiliensis plantation (MacKinnon et al., 1982). Despite its size the reserve is significant as one of the few remnants of low altitude lowland tropical rain forest left on Java (Whitten et al., 1996). Yanlapa is a slightly larger (32 ha) nature reserve, consisting of lowland rainforest on red clay soil, 
relatively well protected and used for scientific study (MacKinnon et al., 1982).

Status: Dungus Iwul is inhabited by a single group of ebony leaf monkeys, which occasionally foray into the surrounding rubber plantation (S. van Balen in litt. 1998; Whitten et al., 1996). In Yanlapa, not only ebony leaf monkeys are present, but also grizzled leaf monkeys (S. van Balen, in litt., 1998).

\section{Mt. Halimun and Mt. Salak}

Counties: Sukabumi, Bogor, Banten.

Habitat: The Halimun National Park covers lowland and hill forest from 500 to $1929 \mathrm{~m}$ (MacKinnon et al., 1982). The park proper totals $400 \mathrm{~km}^{2}$, with some additional lowland forest being situated outside the park boundaries. The Mt. Salak is a 2211 $\mathrm{m}$ tall volcano, well vegetated above the $1000-1200$ $\mathrm{m}$ line. Encroachment from surrounding agriculture and large tea estate enclaves, hunting and illegal gold mining form major threats to the area. Status: The ebony leaf monkey is a well known inhabitant of the Halimun National Park (e.g., Ruhiyat, 1991; MacKinnon 1986), and by virtue of its size the area probably harbours a significant population of the species. Kool (1992) reported of the sighting of four, most likely different groups in the western part of the Halimun reserve; one group in Aug. 1989 (S. van Balen in litt. 1998). Mt. Salak: regularly observed by S. van Balen (in litt., 1998); a group of 7 individuals was observed lower montane rain forest feeding in river valley on the southeastern slopes (Aug. 1997) and one group was heard near Kawa Ratu (Sept. 1998).

Specimens collected: Jasinga: MZB 6694, 3188; Leuwilang: MZB 2344,-5; Mt. Salak: ZMA 5327, RMNH; Cisalak: MZB 558; Bolang: MZB 1876, 560.

\section{Jampang Kulon}

County: Sukabumi.

Habitat: The forests in this rugged and sparsely populated area have partially the status of protection forest, and is scattered into several smaller, and one larger forest block. The altitudinal range lies between sea level and c. $700 \mathrm{~m}$ a.s.1. The Cibanteng Nature Reserve in the northern part of this area and the Cikepuh Game Reserve (together more than $8500 \mathrm{ha}$ ) were established in 1925 and
1973 respectively (MacKinnon et al., 1982). Cibanteng is a coastal lowland forest, and is adjacent to larger Cikepuh Game Reserve. The habitat is mostly secondary forest with patches of primary forest and grassland.

Status: Ladjar and Simanjuntak (1994) studied populations of the species in the Cikepuh Game Reserve and found them present from Citirem to Cibuaya. S. van Balen (in litt., 1998) recorded ebony leaf monkeys in Feb. 1987 in the forests of Ciogong near the village of Sindabarang on the southern coast. Ebony leaf monkeys are probably present in a large number of forest areas within this rugged and sparsely populated area. Furthermore, ebony leaf monkeys may survive in a number of forest areas along the West Javan southern coast possibly from Cikepuh intermittedly to Leuwang Sancang [11].

Specimens collected: Teluk Pelabuan Ratu: ZRC 4380; Cỉwangi: BMNH 1909.1.5.14,-15,-16,-17.

6. Mt. Gede-Pangrango, Puncak, Megamendung, Mt. Pancar

Counties: Bogor, Sukabumi, Cianjur.

Habitat: The Mt. Gede-Pangrango are two wellknown volcanoes, south of Bogor. A pass runs through the Puncak area, with the Gede-Pangrango to the south and Telaga Warna Nature Reserve and Megamendung to the northeast. Although virtually the entire area is enclosed in the 15,000 ha Gede/ Pangrango National Park, ranging from 500-3019 $\mathrm{m}$ a.s.1., encroachment from surrounding agriculture, hunting, and other activities impose continuous threats. The Telaga Warna area forms a $\mathbf{3 5 0}$ ha nature reserve, but the remaining part of the area is much threatened by holiday resorts and encroachment of tea estates. Mt. Pancar is a somewhat isolated hill of $800 \mathrm{~m}$ with moderately disturbed forest on its summit.

Status: Ebony leaf monkeys have been observed in a number of localities, i.e., Pasir Pogor (June 1994), above Selabintana (Sept. 1997), Cibodas (June 1995), the forests near Taman Safari Cisarua (Aug. 1994), Telaga Warna (Sept. 1997), near Cibulau (Aug. 1997), and an isolated population survives on Mt. Pancar (July 1995). The species is most likely to be present throughout the entire forest area. 
Specimens collected: Mt. Pancar: BMNH 1907.6. 18.1; Cikaso: MZB 8008; Mt, Pangrango: RMNH; Cikujang: MZB 6693; Cibodas: BMNH 1949.423, 1954.62, MZB; Sindanglaja: collected by Robinson and Kloss (1919).

\section{Muara Gembong, Muara Angke-Kapuk, Tanjung Sedari}

Counties: Bekasi, DKI Jakarta.

Habitat: Muara Gembong is a mangrove area at the mouth of the Citarum River, c. $60 \mathrm{~km}$ east of Jakarta. In 1981 at least 1000 ha of mangrove forest was left, by 1984 some areas had been converted into rice fields, settlements and fish ponds, and by 1987 the forest were almost completely destroyed (Supriatna et al., 1989). The Muara Angke-Kapuk is a small nature reserve totalling 15.4 ha, west of Jakarta. The area is covered with mangrove forest in a river delta (MacKinnon et al., 1984). Tanjung Sedari is a 8200 ha large proposed nature reserve, wich is presently largely devoid of its mangrove forest (Rombang \& Rudyanto, 1999).

Status: In the Muara Gembong, the ebony leaf monkey lived in groups of up to 30 individuals, at a density of 20 individuals $\mathrm{km}^{-2}$, but currently there is hardly forest left (Supriatna et al., 1989). The Muara Angke supports small populations of ebony leaf monkeys and long-tailed macaques Macaca fascicularis (MacKinnon et al., 1984). Silvius et al. (1987) report of the presence of ebony leaf monkey in Tanjung Sedari. The conversion of mangroves into fish and shrimp ponds and the intensification of shrimp ponds especially along the north coast of Java, increased dramatically during the last decades. Most tall trees dissapeared and it is very hard to find any piece of forest that might be suitable for ebony leaf monkeys. Mauk, another (proposed) nature reserve, that was known for its mangrove and swamp forest (MacKinnon et al, 1982) appeared to be completely devoid of closed forest and/or tall trees (van Balen et al., 1993). If the north coast of West Java still holds additional populations of ebony leaf monkey, regretably these will be small and isolated from one another, making them especially vulnerable to extinction.

\section{Sanggabuana}

Counties: Purwakarta

Habitat: The forests of Sanggabuana or Jati Lahur comprise of c. 5000 ha, approximately 2500 ha of which have been proposed as a recreation forest (MacKinnon et al., 1982). The area is covered with mostly disturbed lowland forest ranging from $\mathrm{c}$. 150 to 1291 , and is centered around the artificial lake of Jati Lahur. Despite being somewhat disturbed, the area is important for the conservation of primates as all three Javan endemics do occur in the area.

Status: The species is reported to be present by B.O. Manullang (pers. comm. 1997); small number of individuals observed in Oct. 1986 (S. van Balen in litt. 1998).

\section{North Parahyangan}

Counties: Bandung, Sumedang, Purwakarta.

Habitat: The highlands around Bandung are collectively known as the Parahyangan (from para: many, and hyang: Gods). The northern part includes a number of tall volcanoes of which the Tangkuban Perahu is the most well known. The area furthermore includes some interesting (proposed) reserves, including the Mt. Tapomas Hunting Reserve (1250 ha), and Burangrang Nature Reserve (2700 ha).

Status: The species is has been reported to be present in Burangrang and Mt. Tapomas (MacKinnon et al., 1982). Wiltjes-Hissink (1953) observed ebony leaf monkeys on the southern slopes of Tangkuban Perahu above Lembang at $1700 \mathrm{~m}$ a.s.l., whereas Rombang \& Rudyanto (1999) report the presence of the species on Mt. Manglayang.

Specimens collected: Subang: ZRC 4374,-5.

\section{South Parahyangan}

Counties: Bandung, Garut, and Cianjur.

Habitat: The extensive mountain forests south of Bandung form a more or less continuous block, locally intersected plantations and roads. Generally forest in the area is forest is extant above c. $1200 \mathrm{~m}$ a.s.1. A number of nature reserves are established in the area, of which the most important ones are Mt. Tilu ( $8,000 \mathrm{ha})$, Mt. Simpang $(15,000$ ha) and Kawah Kamojang ( $8,000 \mathrm{ha})$, six others being less important because of small sizes; more importantly, four new reserves have been proposed 
across the area, totalling a coverage of almost 70,000 ha, ranging from 300 to $2182 \mathrm{~m}$ a.s.1. (MacKinnon et al., 1982).

Status: Ruhiyat (1991) reported ebony leaf monkeys to be present at a number of sites throughout the South Parahyangan, i.e. Mt. Halu, Mt. Tilu, Mt. Papandayan, Kawah Kamojang, the forest near Telaga Patenggang (Mt. Patuha). Most if not all observations were made in areas at $1200 \mathrm{~m}$ a.s.l. and above. MacKinnon et al. (1982) reported the species to be present also on Mt. Simpang. Probably, ebony leaf monkey is present throughout the entire area in numerous isolated populations.

Specimens collected: Pengalengan: RMNH; Tirtasari: RMNH; Cibeureum: RMNH.

\section{Leuweung Sancang \\ County: Garut.}

Habitat: The Leuweung Sancang area contains a 2157 ha nature reserve ranging from sea level to $180 \mathrm{~m}$ a.s.l. The area is covered with sand dunes, mangroves, beach forest and primary rain forest on limestone. The outer parts of the reserve are heavily damaged by illegal tree cutting (MacKinnon et al., 1982).

Status: Ruhiyat (1991) reported the species to be present in the area. Further information is not yet available.

\section{Mt. Ceremai}

Counties: Majalengka.

Habitat: Mt. Ciremaî is a $3078 \mathrm{~m}$ tall volcano south of Ceremai; c. 12,000 ha of forest have been proposed as recreation forest (MacKinnon et al., 1982) Status: There have been no reports on the presence of ebony leaf monkeys, but Napier (1985) reports the presence of twelve skulls from Cirebon, which may have originated from this mountain. Specimens collected: Cirebon: RCS(OM) S70.43(A) (G) (Napier 1985).

\section{Mt. Sawal}

Counties: Ciamis.

Habitat: The forests on Mt: Sawal comprise of an isolated patch of forest of c. $5400 \mathrm{ha}$, which have been designated as a wildlife reserve. Ranging from 600-1704 m a.s.1. the area contains tree species as Altingia excelsa and Podocarpus imbriacata and may be a valuable area for both flora and fauna (MacKinnon et al., 1982). Ceringrin is situated in the lowlands below $200 \mathrm{~m}$ a.s.l, whether or not forest remains is not known.

Status: The species was recorded in a secondary forest patch, on the southern slopes of Mt. Sawal at c. $1100 \mathrm{~m}$ a.s.l and in a patch of Acacia trees (July 1995). The species was not recorded on the northern slopes, but according to local officers of the forestry departement the species is present troughout the reserve.

Specimens collected: Ceringrin: RMNH.

\section{Pangandarang-Karangnini}

Counties: Tasikmalaya, Ciamis.

Habitat: Pangandaran is a small c. 500 ha uplifted limestone peninsula at the southeastern corner of West Java. The area consists of a 38 ha tourist park, adjacent to a 457 ha large nature reserve (MacKinnon et al., 1982). Parts of the area are covered with Teak and Magogany stands, while the remainder consists of rather dry evergreen forest (Whitten et al., 1996). Karangnini consist largely of beach forest and teak forest. The latter is intersected by the Cikabuyatan river, the valley of which is covered with mixed forest.

Status: Pangandaran has been the location where a number of researchers have collected data on ebony leaf monkey (e.g., Brotoisworo, 1983; Brotoisworo and Dirgayusa, 1991; Kool, 1993; Kool and Croft, 1992; Megantara, 1994). The species is very common and in the tourist park and adjacent nature reserve at least 5 different groups observed were fully habituated to the presence of humans (Sept. 1997). Group sizes are relative large in comparison to other West Javan localities. In Karangnini three groups were observed at the mouth of the Cikabuyatan River (Sept. 1997).

Specimens collected: Pangandaran: BMNH 1909.1.5.4,-5,-6(a),-7; Kalipucang: BMNH 1909.1.5.18.

\section{Province of Central Java (including DI Yogyakarta)}

\section{Segara Anakan-Nusa Kambangan \\ Counties: Cilacap.}


Habitat: Sagara Anakan is the shallow bay on the southern coast of Java into which the Citanduy, Cibereum, and other rivers flow. The area consists of a complex of mangrove and tidal swamp forests. South of the area lies the $300 \mathrm{~km}^{2}$ island of Nusa Kambangan. The island largely is under control of the Prison Service of the Minsitry of Justice, as three highly secured prisons are situated on the island. On the island c. 8000 ha of largely undisturbed lowland forest remains.

Status: Erftemeijer et al. (1988) reported ebony leaf monkeys to be present in groups of up to 10 individuals in the 'better' forest areas, i.e., further inland in Segara Anakan. Near Kabujatan, three groups were observed retreating on a small hill after having spent the day in the mangrove forests (Sept. 1997). On Nusa Kambangan (Sept. 1997) no ebony leaf monkeys observed, but the species was known to most of, if not all, of the villagers of Klacis. Apparently the species occurs all over the island.

Specimens collected: Jumblang: MZB 2094; Cilacap: BMNH 1909.1.5.8,-9,-11,-12,-13; Karangbolong: ZRC 4.377.

16. Mts Pembarisan

Counties: Brebes.

Habitat: In this severly under-explored lowland and hill rainforest area on non-volcanic soils, $\mathrm{c}$. 13.000 ha is proposed as a nature reserve (MacKinnon et al., 1982); to the south the area is bordered by extensive Pine plantations, to the east by Teak forest. The area was regarded as one of the most valuable remaing forest in Central Java (MacKinnon et al., 1982).

Status: One group of c. 8 individuals was observed on Mt. Segara, in the eastern part of the Pembarisan mountains (July 1994). No further information is available.

17. Mt. Slamet

Counties: Banyumas, Brebes, Tegal, Pemalang, Purbolinggo.

Habitat: The $3418 \mathrm{~m}$ Mt. Slamet is Java's second tallest mountain. On the wetter southern slopes extensive forest remains down to $700 \mathrm{~m}$ a.s.l. On the eastern slope forest disappeared below 1900 $\mathrm{m}$ a.s.l. Currently the forest above $1000 \mathrm{~m}$ a.s.1. on Mt. Slamet are a proposed nature reserve of
15,000 ha (MacKinnon et al., 1982), while proposals to include the forests at lower elevations have been made (Nijman and Sözer, 1996).

Status: Ebony leaf monkeys have been observed both in natural forest and in Damar plantations on the southern slopes at c. $1500 \mathrm{~m}$ a.s.1. (Seitre \& Seitre, 1990); and observed above Baturaden at $\mathrm{c}$. 700-800 m a.s.l. (April-Aug. 1994; June 1995). The species was also present in oak-laurel forests on the upper eastern slopes above Blambangan, where three groups were observed between altitudes of 2,200-2,800 m a.s.l. (June 1995).

Specimens collected: Kaligua: MZB 6690,-91,-92; Kalikidang: RMNH; Curugilang: RMNH.

18. Mt. Cupu-Simembut

County: Banjarnegara.

Habitat: On these mountains small fragments of natural forest, surrounded by either open ground or pine plantations, remain. The altitudinal range of the forests in this area lies from c. 350-1000 m a.s.1.

Status: Linsley and Nawimar (1994 in BrandonJones, 1995) reported the species to be present in a forest block on a slope of the Tambra river, south of the Argus confluence.

\section{Mts Dieng}

Counties: Pekalongan, Batang, Tenaggung, Wonosobo, Banjarnegara.

Habitat: The mountains north and northwest of the Dieng plateau are still covered with an extensive block of natural forest covering the total range from lowland to upper montane. On the northern foothills of Mt. Lumping above Linggo, the forest (partly a former coffee Coffea spp. plantation abandoned in the 1930s) are forested above c. $300 \mathrm{~m}$, while on the eastern slopes of Mt. Prahu, in the east, only above $1500 \mathrm{~m}$. The forest totals $25,500 \mathrm{ha}$, of which the area above $1000 \mathrm{~m}$ is a proposed game reserve (MacKinnon et al., 1982). Currently the area below $1000 \mathrm{~m}$ a.s.l. is unprotected forest managed by the Ministry of Forestry (Perum Perhutani), but proposals to protect the lowland forests in the western part of the area have been put forward (Nijman and Sözer, 1996). Main threats to the area are planned logging of the lowland forest near Linggo and the conversion into rubber, pine Pinus merkusii, or damar Auracaria spp. plantations. 
Status: A number of groups were observed throughout the lowland and lower montane forest in the westernpart of the Dieng mountains, and in the montane forest in the central and eastern parts (Sept. 1994; June-July 1995; Sept. 1998-Jan. 1999; July 1999-Feb. 2000). The species was reported to be present in the upper montane forests of Mt. Prahu as well. Bartels (1937) reported on the occurrence of mixed groups of $P$. comata and $T$. auratus in the Pagilaran plantation at c. $1300-1500 \mathrm{~m}$ a.s.l. Densities at the lowland forests near Linggo are in the order of 20 individuals $\mathrm{km}^{-2}$ (Nijman and van Balen, 1998).

Specimens collected: Pagilaran: RMNH.

\section{Ceruk Sewu}

County: Temanggung.

Habitat: A small patch of isolated secondary forest on a cliff near a waterfall. The area is used as a tourist resort.

Status: One group of ebony leaf monkeys was observed, most likely only a few other groups might present. The group was observed feeding near the waterfall and seemed partially habituated to the presence of humans (May 1994).

Specimens collected: Candi Roto: RMNH.

\section{Mt. Ungaran}

Counties: Salatiga.

Habitat: This small isolated volcano near Semarang is covered with forest above $1500 \mathrm{~m}$, and a c. 5,500 ha area is proposed as nature reserve (MacKinnon et al., 1982).

Status: What was most likely this species has beep recorded in Oct. 1998 on Mt. Ungaran's western slopes (F. Arga Narata and Sugihartono, pers. comm. 1998), and ebony leaf monkey have been collected nearby, in Gendangan.

Specimens collected: Gendangan: MZB 6695.

\section{Mt. Merapi and Mt. Merbabu}

Counties: Slemen (DI Yogyakarta), Magelang, Blora, Sukoharjo.

Habitat: The twin volcanoes Merapi and Merbabu c. 15,000 ha are proposed as a recreation forest (MacKinnon et al., 1982). The southern slopes of Mt. Merbabu seem to have little remaining natural forest, a situation similar to the northern side of Mt. Merapi. In November 1994 an eruption devastated part of the forest on the southern slopes, but spared most of the forest to the east. The northern slopes have been deforested since long whereas the western slopes are devastated by a permanent outflow of lava. Mt. Merapi is situated north of one of Java's larger cities, Yogyakarta, and is very attractive for recreational purposes.

Status: Ebony leaf monkeys have been observed on the southern slopes above Kaliurang in 1994, a few months prior to the eruption (June 1994). In the following year (July 1995) ebony leaf monkeys were said to be present in small patches of forest on the northwestern slopes of Merapi at c. $1500 \mathrm{~m}$ a.s.l. The species is probably present throughout the area (F. Arga Narata and Sugihartono, pers. comm. 1998).

\section{Mt. Murio}

Counties: Jepara, Kudus, Pati.

Habitat: The peaks of this dormant volcano on Java's northern coast are covered with mostly secondary forest from c. 600-1602 $\mathrm{m}$ a.s.l. The lower, central parts of the complex are cultivated. The forests on Mt. Murio are a proposed nature reserve (MacKinnon et al., 1982).

Status: H.V.J. Sody collected two females at Pangonan at an altitude of $550 \mathrm{~m}$ a.s.1. During two surveys (Aug. 1994; July 1995) in the forest above Colo, no ebony leaf monkeys were observed, although the forest were seemingly still suitable. According to local inhabitants ebony leaf monkeys used to occur here, but nowadays only long-tailed macaques were present. On 3 July 1995 while in the forests near the Jalong coffee plantation on the eastern slopes of Mt. Murio we received information that the ebony leaf monkey is still present in these forests, but the species was not observed by me.

Specimens collected: Pangonan: RMNH.

\section{Cepu}

County: Blora.

Habitat: The region is known for its vast extend of teak forests, which often alternate with small patches of alang-alang Imperata cylindrica grass and secondary vegetation.

Status: Djuwantoko et al. (1994) studied the feed- 
ing behaviour of ebony leaf monkeys in the forests plantations near Cepu. Rappard (1941), residing in the village of Cepu, reported on ebony leaf monkeys in the teak forests nearby. The status remains to be solved, but the species is likely to be present in a number of (isolated) forest areas.

\section{Mt. Lawu}

Counties: Karanganyar.

Habitat: Mt. Lawu is situated on the border between Central and East Java. The upper slopes of the mountain remain forested. The volcano is a popular tourist attraction. A c. 21,000 ha large nature reserve has been proposed (MacKinnon et al., 1982). Status: Ebony leaf monkey were observed on the southern and southeasten slopes at altitudes between 1800-2400 m a.s.l. (Aug. 1994; June-July 1995)

Specimens collected: Mt. Lawu: RMNH.

\section{Province of East Java}

\section{Mt. Liman-Wilis}

Counties: Madiuun, Nganjuk, Kediri, Tuban, Trenggalek, Ponorogo.

Habitat: The mountain complex comprises four summits of which the Liman is the tallest $(2563 \mathrm{~m}$ a.s.1.). Forest fires occur regularly and large parts of the area are covered with shrubs and small trees and sparse Casuarina forest on the upper slopes. The lower southeastern slopes of Mt. Wilis are still well forested, while in the other parts scattered patches of forest remain amidst secondary forest, regrowth, bushes, and plantations. The forests on Mt. Wilis are a proposed 45,000 ha large game reserve, while two small areas, Mt. Sigogor (190 ha) and Picis (28 ha), are long-time registered nature reserves (MacKinnon et al., 1982).

Status: A number of groups of ebony leaf monkeys were observed mainly in the eastern and northern part of the area between altitudes of 1,300 $1,600 \mathrm{~m}$ a.s.1 (July 1995). The species was observed in the primary forests of both nature reserves, as well as in planted pine and acacia stands. Specimens collected: Madiun: BMNH 1938.11. 30.9 .
27. Mt. Penanggunang-Mt. Arjuno

Counties: Modjokerjo, Malang, Pasuruan.

Habitat: The Mt. Kawi and Mt. Arjuno area is presently a mozaic of partly regenerating former coffee plantations, partly degrading lowland, hill and montane forest in varying degrees of disturbance (Smiet, 1992). Only small parts of the area have protection in three existing nature reserves, of which the almost 5,000 ha of Arjuno Lalijiwo is by far the largest. Mt. Pananggunang is situated north of Arjuno, and remains largely covered in forest from c. 600 to the summit at $1653 \mathrm{~m}$ a.s.1. Status: Un Mt. Pananggunang a fair number of groups were observed near the PPLH Centre for Environmental Education, and near the Hindu temples of Candi Colotundo (Aug. 1997). This is probably the locality with the highest percentage of groups containing one or more red individuals. On Mt. Arjuno groups were observed in the lowland forests near the village of Tretes, between 1250 $\mathrm{m}$ a.s.1. and the saddle at $2250 \mathrm{~m}$ a.s.l. at the northern slopes (Aug. 1997), between 1300-1700 m a.s.1. near the hot water springs of Cangar, and at 1500 $\mathrm{m}$ a.s.l. near the Batu Ondo(k) waterfalls, on the southern and southeastern slopes (Sept. 1997, Nov. 1998). Individuals of the erythristic pelage colour morph have been recorded in the area.

Specimens collected: Kawarasan: RMNH; Rembang: BMNH 1938.3.14.2, 1954.57; Arjuno: MZB 1731, -2, ZRC 4378, -9; Mojokerto: BMNH 1938. 11.30.12; Pugeran: MZB 3620.

\section{Mt. Kawi-Kelud}

Counties: Malang, Blitar, Kediri.

Habitat: Some 50,000 ha of continuous forest between the volcanoes of Mt. Kawi and Mt. Kelud ranging from 300 to $2806 \mathrm{~m}$ a.s.l. is a proposed nature reserve (MacKinnon et al, 1982). For a description of the area see Smiet (1992). The area suffers heavily from forest fires.

Status: Three groups observed at altitudes between 1200 and $1700 \mathrm{~m}$ a.s.l. near the waterfalls of $\mathrm{Cu}$ ban Rondo, Mt. Kawi (Sept. 1997). Kohlbrugge (1896) reported on specimens from Lawang. The species has been collected throughout the area. Individuals of the erythristic pelage colour morph have been reported from in the area.

Specimens collected: Blitar: MZB 3372; Batu: RMNH. 
29. Mts Kidul and P. Sempu

Counties: Malang.

Habitat: The Kidul mountains on the southern coast of Malang are covered with some large stands of largely undisturbed lowland rain forest. The Lebakharjo and Bantur forests, respectively covering 13,000 and 5,000 ha, constitute two of the most important areas of lowland forest on Java, and have been proposed as reserves (Whitten et al., 1996; Bekkering and Kucera, 1990). Only a few hundred hectares near Balekambang, receive protection as a recreation forest. Wood cutting and hunting form major threats (MacKinnon et al., 1982). The area is connected through plantations, secondary forest area and separated by a road from the 57,000 ha Mt. Bromo Tengger Semeru National Park. The island of Sempu is situated a few hundred meters of the coast of the Lebakharjo and Bantur forests, and has been designated as a nature reserve.

Status: Observed in Oct. 1989 near the village of Pujiharjo in Lebakhardjo (S. van Balen in litt., 1998). Three groups of ebony leaf monkey observed near Balekambang, both in the beach forest as in the rain forest adjacent to it (Aug. 1997), and the species seems to be present throughout the entire area. Individuals of the erythristic pelage colour morph have been reported to be present by local wardens in Balekambang and Nursahid et al. (1996) reported on the occurrence of erythristic individuals on P. Sempu.

Specimens collected: Wonokoio: RMNH.

\section{Mt. Bromo-Tengger-Mt. Semeru}

Counties: Probolinggo, Malang, Pasuruan, Lumajang.

Habitat: The Bromo-Tengger National Park is best known for its spectacular $10 \mathrm{~km}$ wide Tengger Caldera, its sand sea with squats the active volcano Mt. Bromo. The Mt. Semeru is Java's tallest mountain rising $3,676 \mathrm{~m}$ a.s.l. Its slopes are covered with some undisturbed lower and upper montane forests as well as Casuarina forests.

Status: Van Bemmel-Lenneman and van Bemmel (1940) reported on the occurrence of ebony leaf monkeys in the Tengger mountains, and noted that the species occurs relatively high up, in the surroundings of the Smeroehoeve at $2100 \mathrm{~m}$ a.s.l., and even higher up near the summit of the Semeru. Also van der Veen (1940) recorded a number of ebony leaf monkeys that had died at Semeru's summit. Individuals of the erytristic pelage morphs apparantly were more abundant than the melanic morph (van Bemmel-Lenneman and van Bemmel, 1940). Kohlbrugge (1896) reported on specimens from Puspo. Beudels \& Hardi (1980) list the species for the national park and R. Nursahid (pers. comm. 1998) reported the species to be common on Semeru's western slopes.

Specimens collected: Tosari: RMNH.

\section{Nusa Barung}

County: Jember.

Habitat: Nusa Barung is an island c. 6,000 ha in size, $10 \mathrm{~km}$ of the southern coast of the eastern part of Java. It is covered in deciduous forest and has been a reserve since 1920 (MacKinnon et al., 1982). Timber theft posses a significant threat to the island and most marketable timber has been removed (Whitten et al., 1996)

Status: Whitten et al. (1996) and MacKinnon et al. (1982) reports the presence of ebony leaf monkeys on the island.

\section{Daerah Tinggi Yang}

Counties: Probolinggo, Bondowoso, Jember.

Habitat: The Yang highlands comprise of an undulating plateau between 1,700 and $2,400 \mathrm{~m}$ a.s.l. The vegetation of the plateau mainly consist of Casuarina forests and grassy meadows. The forests are partially enclosed in a 14,500 ha wildlife reserve. Threats to the area include poaching, burning of the grasslands, and use of the area for military exercises (MacKinnon et al., 1982).

Status: MacKinnon et al. (1982) report ebony leaf monkey to be present on the Yang Plateau. The species was reported to be present on Mt. Lamongan, west of the plateau (Aug. 1997). Individuals of the erythristic pelage colour morph have been recorded in the area.

Specimens collected: Jember-Puger RMNH; Jember: MZB 6698; Pegunungan Yang: MZB 1927; Besuki: RMNH.

33. Pasir Putih, Mt. Ringgit and Mt. Beser

Counties: Bondowoso, Panarukan. 
Habitat: Pasir Putih is a popular tourist beach on the northern coast of East Java. Just outside the village some fringes of mangrove forest still can be found. These forest are connected with the deciduous forests on Mt. Ringgit and Mt. Beser by a c. one $\mathrm{km}$ wide strech of teak forest. The forest on Mt. Ringgit and Mt. Beser are among the few remaining areas of deciduous forest left on Java. On Mt. Ringgit c. 2000 ha has been proposed as nature reserve, while on Mt. Beser c. 4000 ha has been proposed as wildlife reserve, both areas should be managed together (MacKinnon et al., 1982). Status: Ebony leaf monkeys have been observed in the mangrove forests near Pasir Putih, and in the teak forests between Pasir Putih and Mt. Ringgit (Aug. 1997, I. Setiawan, pers. comm. 1997). The species is very common on Mt. Ringgit (Aug. 1997); over 6 groups, observed in teak forest, in dense shrubs, and in dry deciduous forest. The erythristic pelage colour morph is present (I. Setiawan and A. Prima Setiadi, pers. comm. 1996), which was confirmed by local inhabitants.

\section{Meru Beteri}

Counties: Jember, Banyuwangi.

Habitat: This 50,000 ha lowland forest ranging from sea level to $1223 \mathrm{~m}$ a.s.l. has the status of national park; it is the last area where the presence of Javan tigers has been confirmed (MacKinnon et al., 1982). The former coffee plantation enclave is presently being abandoned, but encroachment from the outer sides keep threatening the integrity of this important area. The national park is separated by a relatively narrow area of plantations, secondary forest and a road from the Ijen Mountains.

Status: Ebony leaf monkeys are most likely to be present throughout the greater part of the National Park. Hoogerwerf (1972) reported ebony leaf monkeys to be common, especially in the surroundings of Bandi Alat and Sukamade. Bismark and Wiryosoeparto (1980 in Supriatna et al., 1988) studied the species in Meru Beteri, and reported densities of 20 individuals $\mathrm{km}^{-2}$. Seidensticker and Suryono (1980 in Whitten et al., 1996) illustrated the unevenness of ebony leaf monkey in the Meru Betiri National Park, indicating a preference for beach and hill forest.
35. Mts Ijen

Counties: Banyuwangi, Bondowoso, Ampera, Jember.

Habitat: The area is only partly protected by the 2,560 ha nature reserve of Kawah Ijen Merapi Ungup-ungup, and three tiny reserves. More important reserves are proposed for Mt. Raung $(60,000$ ha) in the southwest to Meru Betiri and Maelang $(70,000 \mathrm{ha})$ in the northeast to Baluran National Park (MacKinnon et al., 1982).

Status: A number of specimens have been collected both at Ungup-ungup, as some adjacent sites. Individuals of the erythristic pelage colour morph have been recorded in the area.

Specimens collected: Kendeng III: MZB 705,-6; Ungup-ungup: BMNH 1954.56, MZB 704, ZRC 4372; Sodong Jerok: BMNH 1954.57,-8,-9; Tamansari: BMNH 1954.60, ZRC 4376.

\section{Baluran}

Counties: Besuki.

Habitat: The Baluran National Park totalling 25,000 ha with savannah and monsoon forest centered on the dormant volcano of Mt. Baluran $(1250 \mathrm{~m})$. There is a small moist forest inside the volcano crater, and the extensive coastline is covered with beach forest and mangroves.

Status: A fair number of groups observed in the beach forests near Bama, along the road from Wonorejo to Bekol, and in the savannah near Bekol. Groups up to 25 individuals were not uncommon (Aug. 1997). The species occurs throughout the park, including Mt. Baluran, but is perhaps most easily observed in the beach forest near Bama. The erythristic pelage colour morph occurs in the park (S. Hedges and M. Tyson, pers. comm., 1998). Specimens collected: Bajulmati: BMNH 1954.61; Kosambikamp: MZB 6696,-7,-9, 6700.

\section{Alas Purwo}

Counties: Besuki.

Habitat: Alas Purwo (or Blambangan, or Banyuwangi Selatan) is a 62,000 ha lowland forest reserve ranging from sea level to $360 \mathrm{~m}$ a.s.l. in the driest part of Java. Presently the area is a nature reserve (MacKinnon et al., 1982). Wood cutting forms the major threat to the habitat.

Status: Appelman (1939) recorded ebony leaf 
monkeys in small numbers. Likewise, Hoogerwerf (1972) reported the presence of the species near Pantjur on the western coast, but noted that the species was rather rare. Observed in Nov. 1989 and May 1990 at Gucur near Pasar Anyar, both in natural and teak forest, and near Trianggulasi (May 1990) (S. van Balen, in litt., 1998). The erythristic pelage colour morph occurs in the park (S. Hedges and M. Tyson, pers. comm., 1998).

\section{Island of Bali}

\section{Bali Barat}

Counties: Jembrana, Buleleng.

Habitat: The Bali Barat National Park consists of a large variety of forest types, including (disturbed) savannah, mangroves, and mixed monsoon forest, as well as some sub-montane forests. The national park proper covers an area of just 19,000 ha, but inclusion of the proposed extension to the east would increase it to an area of 77,000 ha.

Status: The species was recorded throughout the year, especially on the Prapat Agung Peninsula (S. van Balen, in litt. 1989). According to Wheatley et al. (1993) the Bali Barat National Park may have the last viable population of ebony leaf monkeys on the island. It is not clear whether their statement refered to the national park proper or that it included the park's eastern extension.

Specimens collected: Sendang: RMNH E 9,

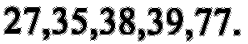

\section{Mt. Batukau}

Counties: Buleleng, Tabanan.

Habitat: Relative undisturbed moist hill, sub-montane and montane forest on recent volcanic soils. The existing three nature reserve are centered around volcanic lakes and totals 1762 ha. An extension as to include the three reserves to one large area covering the whole Batukau complex (c. 20,000 ha) have been proposed (MacKinnon et al., 1982). Status: Pocock (1935) described subspecies stresemanni based on specimens collected by $\mathrm{E}$. Stresemann, from this locality. No further details available. Wheatley et al. (1993) furthermore reported on the possible presence of ebony leaf monkeys near the dry forest on the mountains near
Amlapura, on the eastern part of Bali. Hence, the species might be present in other parts of the mountanous interior of Bali.

Specimens collected: Danau Bratan: BMNH 13. 3.6.1.

\section{Island of Lombok}

\section{Mts Mangsit}

Counties: Lombok Barat

Habitat: Small patch of lowland forest on the western coast of Lombok.

Status: No information available, but the species had been collected in June 1896 (Napier, 1985). Specimens collected: Mangsit: BMNH 1939.1143.

\section{Mt. Rinjani.}

Counties: Lombok Tengah and Timor

Habitat: The Gunung Rinjani National Park covers an area of $40,000 \mathrm{ha}$, of largely montane forest. Despite its excistence since 1941, the park has failed to preserve the once very dense primary forest cover, at least on the northern and northeastern part. Nevertheless, the national park is the only extensive forest complex covering the mountainous northern part of Lombok (MacKinnon and Artha, 1982).

Status: Horst (1935) recorded ebony leaf monkeys in the forests on the southern slopes of Mt. Rinjani, between Sewala and Pusuk up to $1400 \mathrm{~m}$ a.s.l. In May 1990, the species was found at $600 \mathrm{~m}$ a.s.l. south of Bayan (S. van Balen in litt. 1998). Kitchener et al. (1990) reported ebony leaf monkeys to be common on Lombok, and observed groups of one or two individuals on Mt. Rinjani.

Specimens collected: Sembalun: MZB 6688; Sapit: MZB 6689.

\section{Suranadi}

Counties: Lombok Barat

Habitat: Suranadi is a small $(52 \mathrm{ha})$ recreation park c. $25 \mathrm{~km}$ east of the capital city Mataram. The area comprises of mixed moist forest in a small patch around a water source and is important for local water protection (MacKinnon and Artha, 1982). Status: Seen in groups of one or two, with the largest group consisting of 5 individuals (Kitchener et al., 1990). 


\section{Discussion}

\section{Habitat and range}

Figure 1 shows the natural forest cover on the islands of Java, Bali and Lombok (after RePPProT 1990). Note that many smaller forest areas, including coastal fringes of mangrove forest, do not show at the scale used. The map also indicates the fortytwo areas from where the species has been recorded. Undoubtedly, the species might be present in other areas not yet surveyed, but the present listing probably gives a fairly accurate account of the species' distribution. Furthermore, it clearly illustrates the severe degree of fragmentation of populations of ebony leaf monkey, possibly having its effect on the survival of the species.

Oates et al. (1994) erroneously restrict the range of the genus Trachypithecus as far east as the Greater Sundas, excluding Lombok, but include this island, as well as Bali, in the range of the genus Presbytis. $P$. comata ranges on Java as far east as Mt. Lawu, on the border of Central and East Java (Nijman, 1997), but does not occur on Bali or Lombok.

The islands of Java and Bali are situated on the Sunda Shelf, while Lombok forms part of Wallacea, the transition zone between the Oriental and Australian faunal regions. Although not providing a total barrier, the deep water of the Lombok Strait has restricted contact with the Lesser Sunda Islands. In Malesia, primates are largely restricted to the Sundaic region, with only tarsiers Tarsier spp. having reached Sulawesi, and macaques Macaca spp. reaching into Sulawesi and the Lesser Sundas. Ebony leaf monkey is the only colobine that ranges into Wallacea. It has been suggested, firstly by A. Everrett (Hartert, 1896), that the species was almost certainly introduced by Balinese Rajahs on Lombok. Alternatively, the possibility that the species might have been a recent colonizer has been considered (e.g., Eudey, 1987).

De Iongh et al. (1982) observed black monkeys on the Kangean Islands, and reported the possible presence of ebony leaf monkeys on the islands. The Kangean Islands are a group of rather isolated islands situated on the eastern edge of the Sunda Shelf, c. $125 \mathrm{~km}$ east of Madura and c. $125 \mathrm{~km}$ north of Bali. Bergmans and van Bree (1988), re- ferring to the above mentioned observations, reported the possible presence of the species on Kangean and speculated about the introduction of a number of mammals on the islands by humans.

In an attempt to clearify the distribution of ebony leaf monkeys on the Kangean island, I visited Kangean for five consecutive days in August 1997. Throughout the island long-tailed macaques were numerous (cf. de Iong et al., 1982), but no ebony leaf monkey was seen or heard. The pelage of longtailed macaques on Kangean Island is darker than those from mainland Java, and was described as dark grey (rather than brown with a reddish or greyish gloss), often looking blackish under field conditions. For long-tailed macaques to be darker pigmented is a known phenomenon on small islands on the Sunda Shelf (e.g., Simuelue: van Schaik and van Noordwijk, 1985; Nias: Miller, 1903; Karimunjawa and Bawean: Sody, 1949). Local inhabitants and officers of the forestry departement on the island, some of which were familiar with ebony leaf monkeys from mainland Java or Bali, claimed that the species was not present on the island. Both B. van Helvoort (pers. comm. 1997) and Dr Ir H.H. de Iongh (in litt. 1999) do not recall having seen ebony leaf monkeys on the Kangean Islands. In conclusion, ebony leaf monkeys are most likely not present on the Kangean Islands nor are there any indications that they were present in the distant past. The reports of "black monkeys possibly or likely ebony leaf monkeys' (de Iongh et al., 1982; Bergmans and van Bree, 1988), most likely refer to long-tailed macaques, which can have a rather dark pelage coloration on the island.

Ebony leaf monkeys are most likely absent from the island of Madura as well. The island is very arid and virtually all forest has long disappeared (Whitten et al., 1996). During three days of surveying on the island in August 1997 no suitable area of forest was found on the island, and no information indicating the presence of ebony leaf monkeys was received. Few remnants of mangrove forest found on the southern coast between Nipah and Jrengik were to small and the trees too stunted to offer suitable habitat.

Ebony leaf monkey, however, do occur on the islands of Sempu, several hundreds of meters off the coast near the Lebakhardjo and Bantur forests 
[29 in the area account and in Figure 1], and Nusa Barung [31], which is situated $10 \mathrm{~km}$ of the southern coast of the eastern part of Java. At least three scenarios can account for the presence of the species on these islands, none of which is mutually exclusive. Firstly, the ebony leaf monkeys on Sempu and Nusa Barung can be considered relict populations from a time when the sea level was lower as to provide a "land bridge" to the islands. As Nusa Barung is separated from mainland Java by a relative deep strait, this relict population must have become isolated somewhere at the end of the last glacial period, at least 8-10,000 YBP, while for Sempu the separation may be dated somewhat later. Secondly, the species might have been introduced by man. Ships might have transported the animals to the islands, where it was, accidentally or deliberately, set free. Thirdly, the species has been able to (re)colonize suitable islands without the help of man, anytime from the time the islands became separated up to the present day. For long-tailed macaques Wallace (1869) already noted that "this species is very frequent on the banks of rivers, and may have been conveyed from island to island on trees carried down by floods." Similarly, ebony leaf monkeys might have spread naturally east to Lombok. Since the last ice-age there has been more than sufficient time to colonize an island with a similar climate and vegetation, and on which no other (competiting) colobine could exclude it. Given the species ability to occupy mangrove and beach forests, and the relative narrowness of the straits (although the Lombok Strait is broader that the Bali Strait), this possibility cannot be ruled out $a$ priori.

Van der Zon (1978) and MacKinnon (1986; 1987) reported the species to be present in mangrove, swamp, and lowland rainforest up to $1500 \mathrm{~m}$ a.s.l., often near human settlements. Medway (1970) considered its habitat to be inland forest from the lowlands up to almost $2,000 \mathrm{~m}$ a.s.1. Bennett and Davies (1994), in contrast, claim that the species is restricted to coastal and riverine habitats. In fact, the species occurs over a wide range of habitats, from beach forests and swamp forests to dry deciduous forests, and from mangrove, riverine, and lowland rain forest to upper montane forests up to $3,500 \mathrm{~m}$ a.s.l.
Probably the species" ability to cope with considerable amounts of leaves in its diet allows them to live in a large variety of forest types. Ebony leaf monkey occur(red) in the small remnants of mangrove forests on the northern coast of West Java and East Java $[7,33]$, as well as in the larger mangrove and swamp area of Segara Anakan [15], on the south coast of Central Java. It occurs in forests along rivers and waterways and in the fresh water swamp forests [2]. In the western half of the island, it is widely distributed in the pockets of rain forest ranging from sealevel $[1,2,5,10]$ to the upper montane forests at $2,500 \mathrm{~m}$ a.s.l. and above $[6,17,19]$. In the eastern part of its range, it occurs both in the pockets of rain forest both at sea level [34] and on the eastern and southeastern slopes of the higher volcanoes $[27,28,30,41]$, in the fire resistant Cemara Casuarina junghuhni forests $[26,27,32]$, as well as in the dry deciduous forests $[33,36,38]$. In the rain forest environment ebony leaf monkeys seem to be (almost) strictly arboreal, while in the more open forest types, e.g., dry decidious forest and upper montane forest, it seems to be more terrestrial.

The species is able to cope with a certain degree of habitat disturbance. It seems to survive in secondary forest types as well as some man-made forests such as damar Auracaria spp, pine Pinus merkusii, acacia Acacia spp, rasamala Altingia excelsa, rubber Hevea brasiliensis and teak plantations $[2,3,13,14,17,24,26,33]$. Often, however, these plantations are situated adjacent to other more natural forest areas [e.g., 2, 13, 24, 33], while others are intersected e.g., by (river) valleys with a more diverse forest type $[14,17]$. Typically, ebony leaf monkeys are found in or near these natural forest remnants. Alternatively some populations can be found 'trapped' in small fragments of (natural) forest, unable to move out as there is no adjacent forest left [e.g., 3, 20]. Although the species has been observed in a wide range of forest areas, generally it can be assumed that ebony leaf monkeys are dependent on natural forest in one form or another, and that large stands of monocultures offer little if any suitable habitat for the species. 


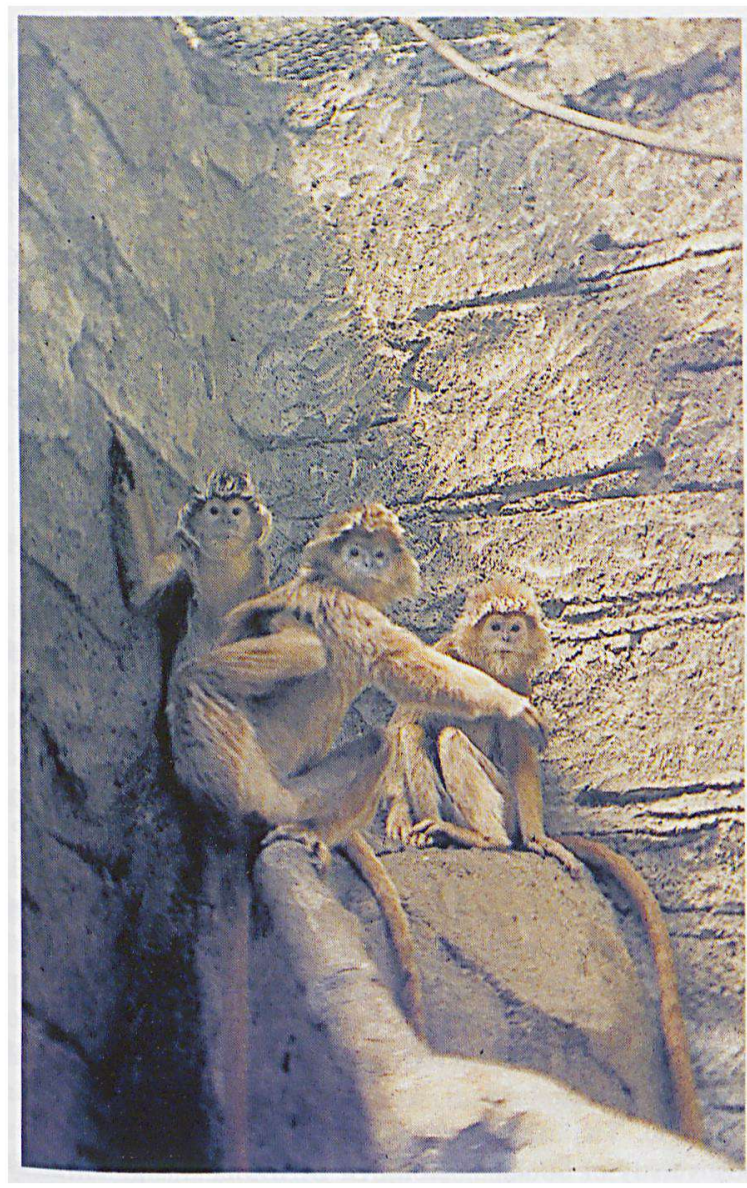

Pl. I. Three individuals of the erythristic pelage morph of ebony leaf monkey Trachypithecus auratus (E. Geoffroy Saint-Hilaire, 1812), Taman Safari Zoo, Cisarua, West Java 1999.

\section{Distribution of the erythristic pelage morph}

The erythristic pelage colour morph (Pl. I and II), besides the more common melanic pelage colour morph (Pl. III), hitherto has only been recorded in East Java. Pfeffer (1965) erroneously reported erythristic individuals to be common in West Java and absent from East Java. Whitten et al. (1996) states that the erythristic occurs in Central and East Java, albeit more common in East Java. Hoogerwerf's (1972) statement that "In Central and East Java another subspecies occurs [ ], among which adult reddish-colored individuals were regularly noted...", may also have given the impression that the erythristic pelage morph also occurs in the central parts of Java. In fact, they have been reported only from the easternmost part of East Java,

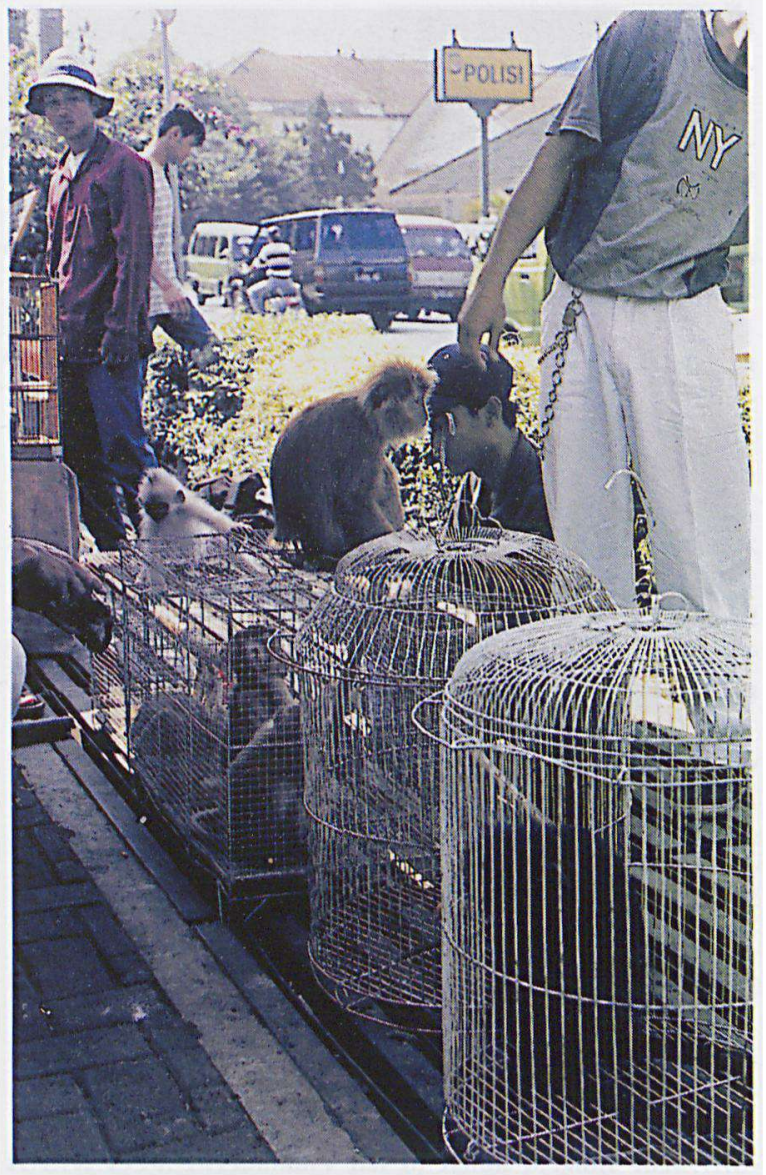

Pl. II. Melanic (foreground in cage) and erythristic pelage morph of ebony leaf monkey Trachypithecus auratus (E. Geoffroy SaintHilaire, 1812), Taman Topi, Bogor, West Java 1999. In Indonesia, many species of primates, including formally protected species, are openly offered for sale, in this particular case in front of the police station. Note that the illegal primate trade includes transports over considerable distances as the nearest site where the erythristic pelage morph occurs [Mt. Penanggunang-Mt Arjuno] is more than $1000 \mathrm{~km}$ by road from Bogor.

i.e., the area bordered roughly in the northwest by Mt. Penanggunang [27] and the surroundings of Modjokerto south, via Wonosalam and Blitar [28] to Mts Kidul near Balekambang [29], east to the southeastern tip of the island at Alas Purwo [37], and north to Baluran [36], and back along the northern coast via Pasir Putih and Mt. Ringgit [33] to Rembang [27] and Mt. Penanggunang (see Figure 1). Although the erythristic pelage morph may be rare in certain areas, it was generally known to inhabitants living in the area. The morph is present in fairly large numbers in the collections of the 


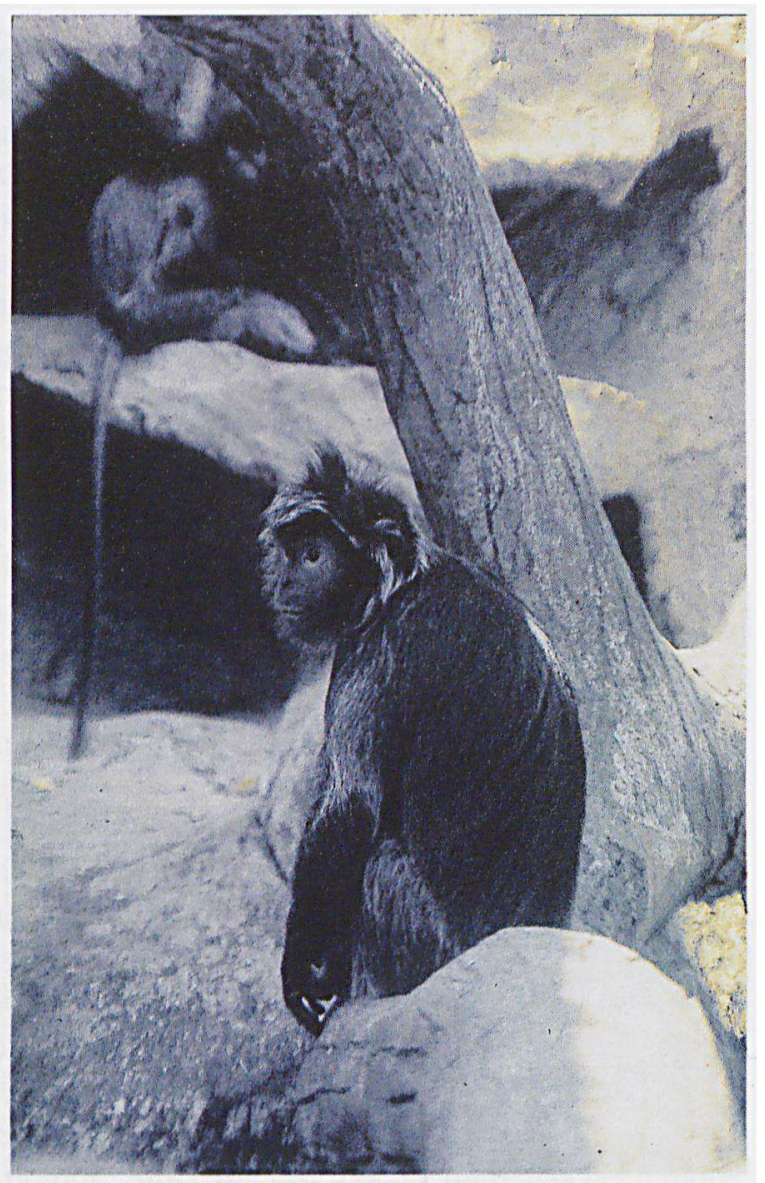

Pl. III. Melanic pelage morph of ebony leaf monkey Trachypithecus auratus (E. Geoffroy Saint-Hilaire, 1812), Taman Safari Zoo, Cisarua, West Java 1999.

various museums visited, indicating a collector's bias towards the rarer type. Various surveys to $\mathrm{Mt}$. Wilis-Liman [26] and Mt. Lawu [25] failed to find erythristic individuals, nor were they known to inhabitants or officers of the forestry departments. Hence, the western boundary of the distribution range of the erythristic pelage morph in all likelihood runs east of Mt. Wilis-Liman. Currently, no erythristic individuals have been recorded in the large teak stands east of Cepu [24], but the area is under-explored. If present, the northern boundary would be extended considerably.

Erytristic individuals have not been recorded from either Bali or Lombok, and it is not known whether they occur on the island of Nusa Barung [31]. They have been recorded on the island of Sempu, south of Mts Kidul [29]. In certain populations, e.g., those in Balekambang, probably only a small proportion of the individuals is of the erythristic pelage colour morph, while in others, e.g., those found in the surroundings of the temples of Candi Colotundo, near Trawas on Mt. Penanggunang, up to $15-20 \%$ of the individuals are. Van Bemmel-Lenneman and van Bemmel (1940) reported the erythristic pelage colour morph to be more common than the melanic pelage morph on Mt. Semeru [30].

\section{Acknowledgements}

The surveys could not have taken place without the cooperation of the Indonesian Institute for Sciences (LIPI), the Directorate General for Nature Conservation and Forest Protection (PKA), the Ministry of Forestry and Estates Crops (MOFEC) and the regional forestry departements, to all of whom I would like to express my gratitude. Drs Boeadi (Museum Zoologi, Bogor), Dr P.J.H. van Bree (Zoological Museum, Amsterdam), Dr P. Jenkins (Natural History Museum, London), and Dr C. Smeenk (National Museum of Natural History, Leiden) are acknowledged for access to specimens under their care. For sharing records of Trachypithecus auratus, for providing other information, or help of various sort I am grateful to: F. Arga Narata and Sugihartono (Kutilang IBC, Yogyakarta), Dr S. van Balen (Agricultural University Wageningen), Dr. T. Geissmann (Institute für Zoologie, Tierärtzliche Hochschule Hannover), S. Hedges (University of Southhampton), Dr B.A. Manullang (formerly WWF-IP), R. Nursahid (KSBK, Malang), A.V. Reijngoud, A.P. Setiadi (YPAL, Bandung), R. Sözer (ISP/ZMA), I. Setiawan and Sujatnika (BirdLife International Indonesia Programme) and M. Tyson (Manchester Metropolitan University). Dr. Ir. H.H. de Iongh and Dr. S. van Helvoort are thanked for providing information on the black monkeys of the Kangean Islands. Dr. H. Albrecht (Dept. Animal Behaviour, University of Amsterdam), Dr C.J. Hazevoet (Museu de História Natural, Lisboa), R. Sözer and an anonymous reviewer made constructive comments on previous versions of the manuscript. Financial support was received from the Faculty of Biology, University of Amsterdam, the Society for the Advancement of Research in the Tropics (Treub-maatschappij), the Netherlands Foundation for International Nature Protection (Van Tienhoven Stichting), and Stichting Het Kronendak. Dr P.J.H. van Bree is thanked for his help throughout the project.

\section{References}

Appelman FJ. 1939. Het schiereiland Poerwo: bosch en wild in Java's Zuidoost-hoek. In: 3 Jaren Indisch Natuurleven, Elfde jaarverslag (1936-1938). Batavia: Ned. Ind. Vereeniging tot Natuurbescherming, 293-298

Balen, S van, Suswelo, IS, Hadi, DS, Soepomo D, Marlon 
R, Mutiarina. 1993. The decline of the Brahminy kite Haliastur indus on Java. Forktail 8: 83-88.

Bartels M. 1937. Zur Kenntnis der Verbreitung und der Lebensweise javanischer Säugetiere. Treubia 16: 149-164.

Bekkering TD, Kucera KP. 1990. The Lebakharjo forest area - natural resources and human interference. Malang: Konto River Project Working Paper, No. 32.

Bemmel-Lenneman $N$ van, Bemmel ACV van. 1940. De vogels van het Tenggergebergte. Trop. Natuur 29: 93101.

Bennett EL, Davies AG. 1994. The ecology of Asian Colobines. In: Davies AG, Oates JF, eds. Colobine monkeys: their ecology, behaviour and evolution. Cambridge: Cambridge University Press, 129-171.

Bergmans W, Bree PJH van. 1986. On a collection of bats and rats (Mammalia: Chiroptera and Rodentia) from the Kangean islands. Z. Säugetierk. 51: 329-344.

Beudels RC, Hardi HB. 1980. Bromo-Tengger/Gunung Semeru proposed national park management plan 1981 1985. Denpasar: Food and Agricultural Organisation of the United Nations.

Brandon-Jones D. 1984. Colobus and leaf monkeys. In: Macdonald D, ed. The encyclopaedia of mammals, Vol. 1. London: Allen and Unwin, 398-408.

Brandon-Jones D. 1995. A revision of the Asian pied leaf monkeys (Mammalia: Cercopithecidae: Superspecies Semnopithecus auratus), with a description of a new subspecies. Raffles Bull. Zool. 43: 3-43.

Brandon-Jones D. 1995. Presbytis fredericae (Sody, 1930), an endangered Colobine species endemic to Central Java, Indonesia. Primate Conserv* 16: 68-70.

Brockelman WY, Ali R. 1987. Methods of surveying and sampling forest primate populations. In: Marsh CW, Mittermeier RA, eds. Primate conservation in the tropical rain forest. New York: Alan Liss, 23-62.

Brotoisworo E. 1983. Population dynamic of Lutung (Presbytis cristata) in Pananjung-Pangandaran nature reserve, West Java. In: Training course on wildlife ecology, May 5-June 15, 1983: Bogor: Biotrop, 1-24.

Brotoisworo E, Dirgayusa IWA. 1991. Ranging and feeding behavior of Presbytis cristata in the Pangandaran nature reserve, West Java, Indonesia. In: Ehara A, Kimura T, Takenaka O, Dirgayusa M, eds. Proceedings of the XIIIth Congress of the International Primatological Society: The Hague: Elsevier Science, 115-118.

Baushop T, Martucei RW. 1968. Ruminant-like digestion of the langur monkey. Science 161: 689-700.

Corbet GB, Hill JE. 1992. The mammals of the Indomalayan region: a systematic review. Oxford: Natural History Museum Publications, Oxford University Press.

Davis DD. 1962. Mammals of the lowland rain-forest of North Borneo. Bull. Nat. Mus. Singapore 31: 1-130, plates I-XXIII.

Djuwantoko, Sulthoni A, Yulianí U, Komarudin H. 1994. Diet and feeding behaviour of Silvered langurs in Teak plantation forest. Kongres I Apapi dan Seminar Nasional Primata III. Depok 13-14 May 1994. Depok: Pusat Studi Biodiversitas Universitas Indonesia.

Erftemeijer P, Balen S. van, Djuharsa E. 1988. The im- portance of Segara Anakan for nature conservation, with special reference to its avifauna. Report No. 5. Bogor: PHPA-Asian Wetland Bureau-Interwader.

Eudey AA. 1987. Action Plan for Asian Primate Conservation: 1987-1991. Gland: IUCN/SSC Primate Specialist Group.

Gaston KJ 1996. Species-range-size distributions: patterns, mechanisms and inplications. Trends in Ecol. Evol. 11 197-201.

Gurmaya KJ, Saryatiman AB, Danardono SN, Sibuea TTH, Adiputra IMW. 1992. A preliminary study on ecology and conservation of the Java primates in Ujung Kulon National Park, West Java, Indonesia. Bandung: Dept. Biology, Padjadjaran University.

Hartert E. 1896. List of a collection of birds made in Lombok by Mr Alfred Everett. Novit. Zool. 3* 591-599.

Hoogerwerf A. 1970. Udjung Kulon, the land of the last Javan Rhinoceros, with local and general data on the most important faunal species and their preservation in Indonesia Leiden: Brill.

Hoogerwerf A. 1972. Verslag over een bezoek aan het Meru Beteri complex, het Blambangan-Purwo of Zuid Banjuwangi wildreservaat, het Ijang hoogland en het Udjung Kulon wildreservaat Javä, Indonesië, in de maanden augustus $t$ m november 1971. Austerlitz: Nederlandse Commisie voor Internationale Natuurbescherming.

Horst O. 1935. Een tocht naar de Segara Anak, het kratermeer van den Rindjani, Lombok. Trop. Natuur 24: 179-186.

Iongh $H$ de, Helvoort B van, Atmosoedidjo $S$, Sutanto $H$. 1982. An ecological survey of the Kangean island archipelago in Indonesia. Unpubl. report, IJselstein.

IUCN. 1994. Preliminary list of Asian primate taxa (November 1994). Gland: IUCN/SSC Primate Specialist Group.

IUCN. 1996. 1996 IUCN red list of threatened animals. Gland: IUCN.

Jablonski D. 1987. Heritability at the species level: analysis of geographic ranges of Creataceous Mollusks. Science 238: $360-363$.

Jones CB 1998. Baseline range size distributions in primates. Primate Conserv, 18: 7-9.

Kartikasari SN. 1986. Studi populasi dan perilaku lutung (Presbytis cristata, Raffles) di Taman Nasional Baluran, Jawa Timor. Bogor: Unp. thesis Institut Pertanian Bogor.

Kay RNB, Davies GA. 1994. Digestive physiology. In: Davies AG, Oates JF, eds. Colobine monkeys: their ecology, behaviour and evolution. Cambridge: Cambridge University Press, 229-249.

Kitchener DJ, Boeadi, Chariton L, Maharadatunkamsi. 1990. Wild mammals of Lombok island. Rec. West. Aust. Mus., Suppl. 33: 1-129.

Kohlbrugge JHF. 1896. Bijdragen tot de natuurlijke geschiedenis van menschen en dieren IV. Zoogdieren van den Tengger. Natuurk. Tijdschr. Ned.-Indië 55: 261-298.

Kool KM. 1992. The status of endangered primates in Gunung Halimun reserve, Indonesia. Oryx 26: 29-33.

Kool KM. 1993. The diet and feeding behavior of the Silver leaf monkey (Trachypitecus auratus sondaicus) in Indonesia. Int. J. Primatol. 14: 667-700.

Kool KM, Croft DB. 1992. Estimators of home range areas 
of arboreal Colobine monkeys. Folia Primatol. 58: 210214.

Ladjar LN, Simanjuntak CN. 1994. Monitoring Macaca fascicularis dan Presbytis cristata pada lokasi Cítírem sampai Cibuaya, suaka margasatwa Cikepuh, Sukabumi, Jawa Barat. Kongres I Apapi dan Seminar Nasional Primata III. Depok 13-14 May 1994. Depok: Pusat Studĩ Bĩodiversitas Universitas Indonesia.

MacKinnon J, Artha MB. 1982. A national conservation plan for Indonesia, Vol IV Nusa Tenggara. Bogor: Food and Agricultural Organisation of the United Nations.

MacKinnon J, Smiet F, Artha MB. 1982. A national conservation plan for Indonesia, Vol III Java and Bali. Bogor: Food and Agricultural Organisation of the United Nations.

MacKinnon K. 1986. Conservation status of Indonesian primates. Primate Eye 29: 30-35.

MacKinnon K. 1987. Conservation status of primates in Malaysia with special reference to Indonesia. Primate Conserv. 8: 175-183.

Maryanto I, Mansjoer I, Sajuthì D, Supriatna J. 1997. Morphological variation in the Ebony and Silver leaf monkeys [Trachypithecus auratus (E. Geoffroy, 1812) and Trachypithecus cristatus (Raffles, 1821)] from Southeast Asia. Treubia 31: 113-131.

Medway Lord. 1970. The monkeys of Sundaland: ecology and systematies of the cercopithecids of a humid equatorial environment. In: Napier JR, Napier $\mathrm{PH}_{\text {, }}$ eds. Old World monkeys: evolution, systematics and behavior. Academic Press, New York, 513-553.

Megantara EN. 1994. A preliminary study on social behaviour of Lutung (Trachypithecus auratus sondaicus) in Pangandaran nature reserve. Kongres I Apapi dan Seminar $\mathrm{Na}$ sional Primata III. Depok 13-14 May 1994. Depok: Pusat Studi Biodiversitas Universitas Indonesia.

Melish R, Dirgayusa IWA. 1996. Notes on the Grizzled leaf monkey (Presbytis comata) from two nature reserves in West Java, Indonesia. Asian Primates 6: 5-11.

Miller GS. 1903. Seventy new Malayan mammals. Smithson. misc. Collns 45: 1-73.

Napier PH. 1985. Catalogue of primates in the British Museum (Natural History) and elsewere in the British Isles. Part III: Familie Cercopithecidae, subfamily Colobinae. London: British Museum (Natural History).

Newton PN, Dunbar RIM. 1994. Colobine monkey society. In: Davies GA, Oates JF, eds. Colobine monkeys, their ecology, behaviour and evolution. Cambridge: Cambridge University Press, 311-346.

Nijman V. 1995. Remarks on the occurrence of gibbons in Central Java. Primate Conserv. 16: 66-67.

Nijman V. 1997. On the occurrence and distribution of Presbytis comata (Desmarest; 1822) (Mammalia: Primates: Cercopithecidae) on Java, Indonesia. Contr. Zool. 66: 247256.

Nijman V, Balen, $S$ van. 1998. A faunal survey of the Dieng Mountains, Central Java, Indonesia: distribution and conservation of endemic primate taxa. Oryx 32: $145-$ 156.
Nijman V, Sôzer R. 1995. Recent observations of the Grizzled leaf monkey Presbytis comata and an extension of the range of the Javan gibbon Hylobates moloch in Central Jawa. Trop. Biodiversity 3: 45-48.

Nijman V, Sôzer R. 1996. Konservasi Elang Jawa dan jenisjenis burung endemik Jawa lainnya: Daerah prioritas kawasan konservasi di Jawa Tengah / Conservation of the Javan Hawk-eagle and other endemic bird species on Java: Priority areas for protection in Central Java. Technical Memorandum 11. Bogor: PHPA/BírdLife International-Indonesia Programme.

Nursahíd R, Astuti M, Tohari H, Jasri MI. 1996. Inventarisasi burung dan mamalia di Pulau Sempu Jawa Timur: Malang: Konservasì Satwa Bagi Kehidupan.

Oates JF, Davies AG, Delson E* 1994. The diversity of living Colobines. In: Davies, GA, Oates JF, eds. Colobine monkeys, their ecology, behaviour and evolution. Cambridge: Cambridge University Press, 45-73.

Payne J, Francis CM, Phillipps K. 1985. A field guide to the mammals of Borneo. Kuala Lumpur and Kota Kĩnabalu: World Wildlife Fund and Sabah Society.

Pocock RI. 1935. The monkeys of the genera Pithecus (or Presbytis) and Pygathrix found to the east of the Bay of Bengal. Proc. Zool. Soc. Lond. 1934, 895-961.

Pfeffer P. 1965. Esquîsse ecologíque de la Réserve de Baluran (Java Est). La Terre et la Vie 112: 197-215.

RePPProT. 1990. The land resources of Indonesia: a national overview from the regional and physical planning program for transmigration: plates I-XIV. London and Jakarta: Land Resources Departement, National Institute Overseas Development Administration and Directorat Bina Program, Directorat Penyíapan Pemukìman, Departmen Transmigrasi.

Robinson HC, Kloss CB. 1919. On five new mammals from Java. Ann. Mag. Nat. Hist. (9) 4: 364-378.

Rombang WM, Rudyanto 1999. Dearah penting bagi burung di Jawa dan Bali. Bogorx PKA/BirdLife International Indonesia Programme.

Ruhiyat Y. 1991. Observations of Presbytis aygula in two localities of Java. Comp. Primat. Monogr. 3:149-191.

Schaik CP, Noordwijk MA van. 1985. Evolutionary effect of the absence of felids on the social organisation of the macaques on the island of Simeulue (Macaca fascicularis fusca, Miller 1903). Folia Primatol. 44: 138-147.

Seitre $L$, Seitre J. 1990. Recent sightings of rare primates on Java. Primate Conserv. 11: 18.

Silvius MJ, Steeman APJM, Berczy ET, Djurharsa E, Taufik AW. 1987. The Indonesia wetland inventory. $A$ preliminary compilation of excisting information on wetlands of Indonesia. Bogor: AWB/Interwader.

Smiet AC. 1992. Forest ecology on Java: human impact and vegetation of montane forest. J. Trop. Ecol. 8: 129-152.

Sody HJV. 1949. Notes on some primates, carnivora, and the babirusa from the Indo-Malayan and Indo-Australian regions. Treubia 20: 121-190.

Supriatna J, Adimuntja C, Mitrasetia T, Willy E, Rufendi D, Manulang BO. 1989. Chemical analysis of food plant parts of two sympatric monkeys (Presbytis aurata and 
Macaca fascicularis) in the mangrove forests of Muara Gembong, West Java. In: Soerianegara I, Zamora PM, Kartawinata $\mathrm{K}$, Umaly RC, Tjitrosomo $\mathbf{S}$, Sitompul DM, Syafii URD, eds. Symposium on mangrove management: its ecological and economical considerations, Bogor 9 . 11 August 1988. Biotrop Special Publication No. 37. Bogor: SEAMEO-Biotrop, 161-169.

Veen $\mathbf{R}$ van der. 1940. Het sterven van dieren op vulkaantoppen. Trop. Natuur 20: 27-28.

Wallace AR. 1869. The Malay Archipelago: the land of the Orang-utan, and the Bird of Paradise. New York: Harper and Brothers.

Waterman PG, Kool KM. 1994. Colobine food selection and plant chemistry. In: Davies $\mathrm{AG}_{\text {, Oates JF, eds. Colobine }}$ monkeys: their ecology, behaviour and evolution. Cambridge: Cambridge University Press, 251-248.

Weitzel V, Groves CP. 1985. The nomenclature and taxonomy of the Colobine monkeys of Java. Int. J. Primat. 6: 399-409.

Weitzel V, Yang CM, Groves CP. 1988. A catalogue of primates in the Singapore Zoological Reference Collec- tion, Department of Zoology, National University of Singapore (formerly the Zoological Collection of the Raffles Museum). Raffles Bull. Zool. 36, 1-166.

Wheatley BP, Fuentes A, Harya Putra DK. 1993. The primates of Bali. Asian Primates 3: 1-2.

Whitten T, Soeriaatmadja RE, Afiff SA. 1996. The ecology of Java and Bali, the ecology of Indonesia series Vol II: Singapore: Periplus Editions.

Wiens JA 1992. The ecology of bird communities Volume 1: foundations and patterns. Cambridge studies in ecology. Cambridge: Cambridge University Press.

Wiltjes-Hissink EA. 1953. Twee excursies naar de Tangkuban Perahu. Trop. Natuur 33: 115-119.

Wolfheim JH. 1983. Primates of the World. Distribution, abundance, and conservation. Seattle and London: University of Washington Press.

Zon APM van der. 1978. Mammals of Indonesia. FO/INS/ 78/061 Bogor: UNDP/FAO National Park Development Project.

Received: 6 July 1999 